UDC 81.111'42

DOI https://doi.org/10.32447/2663-340X-2020-7.16

\title{
POETIC MEANS OF REVEALING UNCERTAINTY IN POSTMODERN EXPERIMENTAL TEXTS
}

\author{
Zavarynska Maria Serhiivna \\ Postgraduate Student at the Department of Translation Studies and Contrastive Linguistics \\ named after Hryhoriy Kochur \\ Ivan Franko National University of Lviv \\ Universytetska Street, 1, Lviv, Ukraine
}

\begin{abstract}
This article deals with the notion of "poetics", "rhizome", poetic means of uncertainty revealing through rhizome principles in postmodern experimental texts (PET). Literature as an experiment is typical for postmodern philosophy (XX-XXI c.), a period of irreversible changes in culture, spirituality, science, politics, economics and social tendencies in general. Postmodernism is an outlook that reflects tendencies and benchmarks of contemporary society and an emergence of experimental texts is a logical stage in literature development. The basic statement of the research is that a word in a literary context of PET is enriched by meanings and starts to function in a specific entity called rhizome - a fundamental category of postmodern outlook. Rhizome as a flexible, non-linear, non-hierarchical system of text formation produces uncertainty. It is proved that uncertainty leads to multiplicity of meanings which enables the author to "play" with the reader and leaves open the possibility of free text interpretation. A text form, not text content, plays the main role in PET. The reader should use critical thinking due to difficulties in reading PET such as multiplicity of realities, interpretations and which are seemed to be intentionally created by the author. The research demonstrates that uncertainty can be realized by the following poetic means: lipogram, pangram (holoalphabetic sentence), mondegreen, antithesis, personification and some rhizome principles that include multiplicity (intertextuality means), connection and heterogeneity, "asignifying rupture", cartography and decalcomania (applying of antimyth, mythologeme). The article research makes a contribution to the study and development of universal methods of revealing uncertainty through poetic means in PET.

Key words: poetics, uncertainty, rhizome, postmodernism, experimental text.
\end{abstract}

Introduction. Poststructural philosophy of XX-XXI c. has influenced greatly contemporary literature, which under these circumstances has become totally experimental. Wide spread of PET is caused, to my mind, by readers' postmodern outlook, in which experiment is taken as a basic method of investigation, on one hand, and their ability to produce multiplicity of answers and meanings, on the other. Despite the fact that there is a number of researches dedicated to poetic peculiarities of postmodern literary texts, these issues leave much to be clarified, particularly in poetic essence of PET.

Theoretical framework. Poetic analysis of PET seems to be fruitful while revealing specific "aesthetics of chaos" of PET created by uncertainty as the key feature of those texts. Scientific works of postmodern classicists and theorists such as G. Deleuze, F. Guattari, R. Barthes, M. Foucault, J. Derrida, J.-F. Lyotard are analyzed and taken as theoretical basis of the article. In particular the latest researches of O. A. Babelyuk, I. A. Bekhta, O. V. Kolyasa dedicated to genre and stylistic investigation of postmodern literary texts as well as exploration of rhizome and its principles applied to such texts are also of great importance for this research. PET of different XX-XXI C. authors serve as illustrative material for revealing poetic means of uncertainty.

The aim of the article is to examine poetic means of revealing uncertainty in PET. The aim requires realization of the following tasks: to identify the notions of "poetics", "rhizome", "uncertainty", to define uncertainty as the basic feature of PET. The object of the article is a range of poetic means which create uncertainty in PET.

Research findings. PET as a literary genre is a logical stage in the development of contemporary literary process which is greatly influenced by postmodern outlook. The term "PET" includes postmodern prose genres (antinovel, shortshort story, "hint" fiction, purple prose etc.) and postmodern poetry genres (palindrome, acrostic, visual poetry, holorime, concrete poetry etc.). PET emerges as a product of innovation period in human history in all spheres of everyday life and the non-stop IT development raging from the second half of the XXc. to the beginning of the XXI C. While creating PET the author violates classic canons of text formation combining formerly incompatible genres, styles, extraordinary forms and wordplay. 
A distinctive characteristic of postmodern outlook is rhizome (from Ancient Greek: rhízōma "mass of roots"), a notion that implies non-linear method of entity arrangement. Rhizome is a fundamental postmodern category in the course of postmodern art study in general and postmodern poetics in particular, which produces such specific features of PET as simulation, irony, fragmentation, decentering, and uncertainty among them. By the way, a concept of rhizome was firstly represented by French philosophers G. Deleuze and F. Guattari in their "Capitalism and Schizophrenia" (1972-1980) project [10]. It is based on the comparison of rhizome and a tree: while a tree is ruled by linearity and hierarchy, rhizome is unbounded and distributed. Rhizome is a means that denotes an alternative to closed and static structures with an axial orientation. The culture of "tree structure" includes classic genres and outlook while "rhizome structure" is a non-linear connection between the world and culture which produces multiplicity of relations and symbioses.

There is a number of principles of rhizome formation typical for PET. Among them: multiplicity (never-ending game of meaning diffusion where narration lines link the author, the reader, the characters), connection and heterogeneity (no dominant point in a text that dictates a single meaning, one point of a "root" can be connected to the other), "asignifying rupture" (ripped root of rhizome continues growing and doesn't mean incompleteness but a new twist, for example, unfinished plot line make the reader create the ending of his own, to his liking), cartography and decalcomania (rhizome is a map with multiplicity of entrances rather than a calque which copies). In the most general sense a rhizome concept may be applied as a scheme of connection among different types of scientific knowledge becoming a flexible method of investigation. All these abovementioned rhizome principles form uncertainty, which became a dominant feature of PET.

The uncertainty phenomenon is interpreted as a key feature of a postmodern literary text in the context of postmodern poetics. Under its influence the meaning of the text is not on the surface, not simply hiding but try to "escape" from a reader [1]. Such outstanding post-structuralism theorists as U. Eco, I. Hassan, F. Jameson, E. Kafalenos consider uncertainty to be the fundamental characteristic of postmodernism in general. Application of uncertainty to linguistics, namely to postmodern poetics is possible due to indeterminism philosophy of a free will which emerged in ancient times. That is owing to a possibility of a free text interpretation performed by the reader.
The concept of J. Derrida, a French philosopher, is considered to be the basis in postmodern theory. According to J. Derrida, "the world is the text, and the text is the only possible model of reality", which is not original, not new. That's why a French philosopher R. Barthes introduced the notion of "the death of the author" which refers to the multiplicity of a postmodern text caused by the reader not by the author (the essay "The Death of the Author", 1968) [17]. Hence, any postmodern text is a specific, unique expression of "global writing", produced by a team work of the reader and the author as an example of their experimental interrelations.

The notion of experimental literature (EL) appeared in XVIII C. and signified literary texts in prose genre, with such features as innovative technique and writing style. The first experimental text is considered to be the novel of L. Sterne "The Life and Opinions of Tristram Shandy, Gentleman" (1759) [14] due to its violation of novel cannons of that time, extraordinary text structure and rhizome narration which became the basis of antinovel principles.

An experiment, which lies in the heart of PET, is a justified method of cognition in all spheres of life because of its universality, particularly in the context of postmodern vision. EL, at its core, is a specific innovative activity of the author aimed to rebirth a literary language, the role of the author and approaches of text perception. The key features of PET include: displaying the unreal world, experimenting with typography and format of the text, mixing several genres in one literary text, developing reader's critical thinking.

Thus, uncertainty in PET may be viewed in two ways: as an unintentional result of the experimenting with a text and as a number of specific poetic means used by the author intentionally to create multiplicity of textual meaning and entertain the reader. In both cases uncertainty in PET creates a unique "aesthetics of chaos" which becomes an inexhaustible source for an analysis of its poetics. By the way, under poetic analysis of PET we mean poetic means which are tricky applied in order to form literary peculiarities of PET.

In ancient times the term "poetics" (from Greek "poietike" - creative, productive) [16] meant the study about fiction. In a broader sense poetics is regarded as a theory of literature, in a narrow sense it can be interpreted as the investigation of literary language (stylistic expressive means and stylistic devices) of any literary text of any author. The direct aim of poetics is investigation of principles of literary text formation through description and classification of different poetic means. 
Poetics is divided into "general poetics" that investigates author's literary approaches to express the idea in a text and rules of combination of these approaches. Literary devices or poetic means can be classified according to levels where the idea of a text is located; "descriptive poetics", which deals with the description of structure of literary text when separate levels and parts considered to be a single whole; "historical poetics" that examines the development of literary devices and categories of a particular epoch.

Poetics of PET is based on rhizome approach and reveals the emergence of new hybrid literary forms. That's why the poetics of postmodern texts is connected with such metaphorical characteristics as "disharmonious harmony", "assymetrical symmetry", "dualism poetics" etc. [4, 118]. According to V. Ivanov [3, 936-943], in the most general sense poetics is a study that examines literary text structure/formation and system of aesthetic devices applied to it. Uncertainty, as plurality of meanings, or the so called "lexical polyphony", can be created by means of wide poetic context which may cover a text passage or the whole text $[6,135]$.

The theory of J. Cazares, Y. Naida, O. Savchenko claims that compatibility is the key reason why a word in each context gets different meanings. The essential feature of poetic style is the compatibility of poetic means but compatibility of different meanings is perceived as intentional multiplicity. Narrow context offers one meaning while wide context produces a number of associations and connotations [5, 27]. This multiplicity of interpretations leads to "desctruction of expected connotations". Text formation became extraordinary to such an extent that the reader often feels cheated and confused during identifying an appropriate meaning of a word.

As an example of an experiment with poetic means let's consider M. Kington's bizarre holorime (from Greek: a form of rhyme where two very similar sequence of sounds can form phrases composed of slightly or completely different words and with different meanings [11] "A Scottish Lowlands Holiday Ends in Enjoyable Inactivity" (2003): "In Ayrshire hill areas, a cruise, eh, lass?" Inertia, hilarious, accrues, helas!" (1). "Helas" is an exclamation of woe or disappointment, related to alas. Backwords both lines are pronounced almost identically ("In Ayrshire" is pronounced roughly like "iTertia").

The novel by M. Dunn "Ella Minnow Pea", or "Ella Minnow Pea: a progressively lipogrammatic epistolary fable"(2001) impresses with its structure. Lipogram (from Greek: "leaving out a letter") is constrained writing or word game consisting of writing paragraphs or longer works in which a particular letter or group of letters is avoided [13]. The plot of M. Dunn's novel is presented through mail or notes sent between various characters. The book is called "progressively lipogrammatic" which means that during the development of the story more and more letters of the alphabet are excluded from the characters' writing. As letters disappear, the novel becomes more and more phonetically or creatively spelled. Thus, the base of the plot of "Ella Minnow Pea" are the pangrams, or holoalphabetic sentences (from Greek: "every letter" - a sentence using every letter of a given alphabet at least once): "The quick brown fox jumps over the lazy dog" and "Pack my box with five dozen liquor jugs" (4).

Postmodern authors of PET also use mondegreen (a mishearing or misinterpretation of a phrase as a result of near-homophony, in a way that gives it a new meaning) which can be also considered as a device of uncertainty [2][9]. The term mondegreen was created by S. Wright in 1954 who had misheard the lyric "laid him on the green" in the Scottish ballad "The Bonny Earl of Murray" as "Lady Mondegreen" [18].

Rhizome principle of multiplicity can be realized with the usage of intertextuality, the notion firstly presented by J. Kristeva and signifies the shaping of a text's meaning by another text [12]. As the example one can choose an absurdist play "Rosencrantz and Guildenstern Are Dead" by T. Stoppard (1966) in which the author uses two minor characters from W. Shakespeare's "Hamlet" (1599-1601). Furthermore, "Hamlet" is based on a legend of Amleth, what we might call "double intertextuality".

"CLAUDIUS: Welcome, dear Rosencrantz... (he raises a hand at GUIL while ROS bows - GUIL bows late and hurriedly.)... and Guildenstern. (He raises a hand at ROS while GUIL bows to himROS is still straightening up from his previous bow and half way up he bows down again. With his head down, he twists to look at GUIL, who is on the way up.) Moreover that we did much long to see you, the need we have to use you did provoke our hasty sanding (ROS and GUIL still adjusting their clothing for CLAUDIUS'S presence.)" (5).

T. Stoppard creates his own W. Shakespeare's like lines, but sometimes leaves the text directly from original version. The reading of such text requires additional knowledge of the reader who should have read "Hamlet" before to understand the purpose of Stoppard's commentary on it. As we can observe, such experimental intertextual insertings compose a specific textual structure, style, polyphony and 
serve as linkers among other texts, expanding text boarders and understanding to endlessness.

Rhizome principle of cartography and decalcomania can be realized due to the usage of antimyth, a belief or system that opposes a myth or myths [7]. There is "an underlying commonality" to myth and ritual of traditional societies and the antimyth of modern, technological society $[10,86]$.

Applaying antimyth suggests the usage of a traditional mythologeme (a basic core element, motif or theme of a myth) with "rebound effect". For example, a postmodern American writer D. DeLillo's in his novel "Cosmopolis" (2003) uses a mythologeme of New York city by analogy of J. Joice's mythologeme of Dublin in the novel "Ulysses" (1922). In "Cosmopolis" New York city is not only the place of the odyssey but also acts as the main character. The big city determines the fate of people who are only parts of it and transform their personalities. The image of big city makes the impression of ominous and dark place: "The city eats and sleeps noise. It makes noise out of every century" $(3,71)$. Thus, we observe personification (an anthropomorphic metaphor, occurs when a thing or abstraction is represented as a person) [15].

Another example of an experiment with poetic means is a book of very short stories called "Almost No Memory" (1997) by L. Davis who considered to be a crowned master of the very short story of modern times. For instance, in the very short story "The Outing" there is an applying of antithesis (from Greek "setting opposite", a figure of speech involving a seeming contradiction of ideas, words, clauses, or sentences within a balanced grammatical structure. Parallelism of expression serves to emphasize opposition of ideas) [8]:
"An outburst of anger near the road, a refusal to speak on the path, a silence in the pine woods, a silence across the old railroad bridge, an attempt to be friendly in the water, a refusal to end the argument on the flat stones, a cry of anger on the steep bank of dirt, a weeping among the bushes" (2).

"The Outing" serves as the skeleton of a story in which emerges an opposition between nature landscapes and human problems. The aim of antithesis applying here is displaying of nature superiority over a human.

Conclusions. The concept of rhizome is essential in PET formation where the key feature is uncertainty. Therefore, during PET formation the author and the reader enter the "bilateral negotiations" which produce special reality with specific poetics when the linear plot is dismissed in favor of fragmentation. Each poetic mean can be interpreted differently due to the context that, for its part, acquires "multiple shades" soaked in uncertainty. Reading of PET requires skills to navigate in the text field. The sense of poetic analysis lies in investigation of a text taking into account its literary, compositional and plot peculiarities. Poetic analysis enables to infer how the combination of poetic means can influence on the image. Uncertainty can be realized by rhizome principles such as multiplicity, connection and heterogeneity, "asignifying rupture", cartography and decalcomania. Results of the research in the article represents the value in exploring of universal methods of revealing uncertainty through poetic means in PET. Thus, the perspective of further research is to investigate different poetic means of revealing uncertainty in the context of the latest PET and work out methods which help to monitor that "desctruction of expected connotations" in PET.

\section{BIBLIOGRAPHY}

1. Бабелюк О. А. Принципи постмодерністського текстотворення сучасної американської прози малої форми: монографія. Дрогобич: Вимір, 2009. 296 с.

2. Борисова Е. Б. Художественный образ в английской литературе XX века: типология-лингвопоэтика-перевод: диссертация доктора филологических наук: 10.02.04, 10.02.20. Место защиты: Поволж. гос. соц.-гуманитар. акад. Самара, 2010. 383 c.

3. Иванов В. В. Поэтика. Краткая литературная энщииклопедия (КЛЭ), 1968. Т. 5. 936-943 с.

4. Маньковская Н. Б. Париж со змеями (Введение в эстетику постмодернизма). М.: ИФРАН, 1995. 271 с.

5. Сиротіна В.О. Про специфіку словесних значень у художньому тексті. Мовознавство, 1981. № 1. С. 34-42.

6. Урнов Д. М. Литературное произведение в оценке англо-американской «новой критики». М, 1982. 261 с.

7. Antimyth // Wiktionary, the free dictionary. https://en.wiktionary.org/ [Electronic Resource]. URL: https://en.wiktionary.org/wiki/antimyth (accessed 21.06.2020)

8. Antithesis // Wikipedia, the free encyclopedia. https://en.wikipedia.org/ [Electronic Resource]. URL: https://en.wikipedia.org/wiki/Antithesis (accessed 18.06.2020)

9. Carroll J. "Zen and the Art Of Mondegreens". 1995. URL: https://sfgate.com/

10. Deleuze G., Guattari F., Massumi B. A Thousand Plateaus: Capitalism and Schizophrenia. University of Minnesota Press, 1987. $632 \mathrm{p}$. 
11. Holorime // Wikipedia, the free encyclopedia. https://en.wikipedia.org/ [Electronic Resource]. URL: https://en.wikipedia.org/wiki/Holorime (accessed 08.06.2020)

12. Intertextuality // Wikipedia, the free encyclopedia. https://en.wikipedia.org/ [Electronic Resource]. URL: https://en.wikipedia.org/wiki/Intertextuality (accessed 28.05.2020)

13. McArthur T. The Oxford Companion to the English Language, Oxford University Press, 1992. 1184 p.

14. Miller F. P., Vandome A. F., McBrewster J. Experimental Literature. Mauritius: VDM Publishing House, 2010. $76 \mathrm{p}$.

15. Personification // Wikipedia, the free encyclopedia. https://en.wikipedia.org/ [Electronic Resource]. URL: https://en.wikipedia.org/wiki/Personification (accessed 10.06.2020)

16. Poetics // Wikipedia, the free encyclopedia. https://en.wikipedia.org/ [Electronic Resource]. URL: https://en.wikipedia.org/wiki/Poetics (accessed 28.05.2020)

17. Seymour L. Roland Barthes' The Death of the Author. The Macat Library. 2018. 96 p.

18. Wright S. The Death of Lady Mondegreen. Harper's Magazine 209, 1954. 48-51 pp.

\section{REFERENCES}

1. Babelyuk O. A. (2009). Pryntsypy postmodernists'koho tekstoznavstva suchasnoho amerykans'koho prozy maloyi formy: monohrafiya [Principles of postmodern text formation of contemporary American short fiction: monograph]. Drohobych: Vimir. 296 s. [in Ukrainian].

2. Borisova Ye. B. (2010). Khudozhestvennyy obraz v angliyskoy literature XX veka: tipologiya-lingvopoetikaperevod: dissertatsiya doktora filologicheskikh nauk [Literary image in English literature of XX c.: thesis of Doctor of Philology]: 10.02.04, 10.02.20. Mesto zashchity: Povolzh. gos. sots.-gumanitar. akad. Samara. 383 s. [in Russian].

3. Ivanov V. V. (1968). Poetika. Kratkaya literaturnaya entsiklopediya (KLE) [Poetics. Short literature encyclopedia]. T. 5. 936-943 s. [in Russian].

4. Man'kovskaya N. B. (1995). Parizh so zmeyami (Vvedeniye v estetiku postmodernizma) [Paris with snakes (Introduction to postmodern aesthetics].. M.: IFRAN. 271 s. [in Russian].

5. Syrotina V.O. (1981). Pro spetsyfiku slovesnykh znachen' u khudozhnyomu teksti. Movoznavstvo [About specificity of lingual meanings in literary text]. № 1. 34-42 s. [in Ukrainian].

6. Urnov D. M. (1982). Literaturnoye proizvedeniye v otsenke anglo-amerikanskoy "novoy kritiki" [Literary text in the evaluation of English-American "new criticism". M. 261 s. [in Russian].

7. Antimyth // Wiktionary, the free dictionary. https://en.wiktionary.org/ [Electronic Resource]. URL: https://en.wiktionary.org/wiki/antimyth (accessed 21.06.2020)

8. Antithesis // Wikipedia, the free encyclopedia. https://en.wikipedia.org/ [Electronic Resource]. URL: https://en.wikipedia.org/wiki/Antithesis (accessed 18.06.2020)

9. Carroll J. (1995). "Zen and the Art Of Mondegreens". URL: https://sfgate.com/

10. Deleuze G., Guattari F., Massumi B. (1987). A Thousand Plateaus: Capitalism and Schizophrenia. University of Minnesota Press. 632 p.

11. Holorime // Wikipedia, the free encyclopedia. https://en.wikipedia.org/ [Electronic Resource]. URL: https://en.wikipedia.org/wiki/Holorime (accessed 08.06.2020)

12. Intertextuality // Wikipedia, the free encyclopedia. https://en.wikipedia.org/ [Electronic Resource]. URL: https://en.wikipedia.org/wiki/Intertextuality (accessed 28.05.2020)

13. McArthur T. (1992). The Oxford Companion to the English Language, Oxford University Press. 1184 p.

14. Miller F. P., Vandome A. F., McBrewster J. (2010). Experimental Literature. Mauritius: VDM Publishing House, $76 \mathrm{p}$.

15. Personification // Wikipedia, the free encyclopedia. https:/en.wikipedia.org/ [Electronic Resource]. URL: https://en.wikipedia.org/wiki/Personification (accessed 10.06.2020)

16. Poetics // Wikipedia, the free encyclopedia. https://en.wikipedia.org/ [Electronic Resource]. URL: https://en.wikipedia.org/wiki/Poetics (accessed 28.05.2020)

17. Seymour L. (2018). Roland Barthes' The Death of the Author. The Macat Library. 96 p.

18. Wright S. (1954). The Death of Lady Mondegreen. Harper's Magazine 209. 48-51 pp.

\section{ILLUSTRATIVE SOURCES}

1. 5 Poems With Amazing Wordplay. https://www.mentalfloss.com/article/504101/5-poems-amazing-wordplay [Electronic Resource]. - URL: https://www.mentalfloss.com/article/504101/5-poems-amazing-wordplay (accessed 29.05.2020)

2. Davis L. (1997). Almost No Memory: Stories. Farrar, Straus \& Giroux. 193 p.

3. DeLillo D. (2003). Cosmopolis. Picador. 209 p. 
4. Pangram // Wikipedia, the free encyclopedia. https://en.wikipedia.org/ [Electronic Resource]. - URL: https://en.wikipedia.org/wiki/Pangram (accessed 07.06.2020)

5. Stoppard T. (1994). Rosencrantz and Guildenstern Are Dead. Grove Press. 126 p.

\title{
ПОЕТИКА НЕВИЗНАЧЕНОСТІ В ПОСТМОДЕРНІСТСЬКИХ ЕКСПЕРИМЕНТАЛЬНИХ ТЕКСТАХ
}

\author{
Заваринська Марія Сергіївна \\ аспірант кафедри перекладознавства і контрастивної лінгвістики імені Григорія Кочура \\ Львівського національного університету імені Івана Франка \\ вул. Університетська, 1, Львів, Украӥна
}

У статті розглянуто поняття “поетика”, “ризома”, засоби вираження невизначеності як ключової риси постмодерністських експериментальних текстів (ПЕТ). Література як експеримент притаманна концепиії філософії постмодернізму (XX-XXI cm.), періоду потоку незворотних змін у культурі, духовності, науці, політиці, економіиі та соиіальних тендениій загалом. Постмодернізм - світогляд, який відображсає тенденщії й орієнтири сучасного суспільства, а поява експериментальних текстів є логічною сходинкою у розвитку сучасної літератури. У статті йдеться, що слово в художньому контексті ПЕТ збагачується сенсами, починає функиіонувати в ключі специифічного иілого - ризоми, основної категорії постмодерністського світогляду. Ризома як гнучка, нелінійна, неієрархічна система організації тексту породжує невизначеність. Доведено, щзо невизначеність як експеримент призводить до множинності значень, що дає змогу авторові “бавитися” з читачем, залишати можливість вільного прочитання тексту. Важливу роль у поетииі ПЕТ відіграє не стільки зміст, скільки форма художнього тексту. Автори ПЕТ навмисно створюють труднощі у прочитанні, будуючи множсиність реальностей, трактувань і спонукаючи читача до критичного мислення. У дослідженні виявлено, що невизначеність може реалізуватися за допомогою таких поетичних засобів, як ліпограма, панграма, мондегрін, антитеза, персоніфікація, та відповідних ризоматичних принципів: множинності (засоби інтертекстуальності), зв 'язку тагетерогенності, незначущого розриву, картографіі та декалькоманії (використання антиміфу, міфологеми). Результати досліджень у статті становлять певний внесок у вивченні та розробиі універсальних методів виявлення невизначеності крізь призму поетичних засобів в ПЕТ.

Ключові слова: поетика, невизначеність, ризома, постмодернізм, експериментальний текст. 